\title{
CODE MIXING IN TV SHOW ENTITLED HIJAB TRAVELING ON TRANS7
}

\author{
Sri Arfani \\ Universitas Bina Sarana Informatika Jakarta \\ sri.saf@bsi.ac.id \\ Nafiah Mahmudah \\ Universitas Bina Sarana Informatika Jakarta \\ Nafmahmudah899@gmail.com
}

\begin{abstract}
APA Citation: Arfani, S. and Mahmudah, M. (2020). Code mixing in TV show entitled Hijab Traveling on Trans 7. Journal of English Language and literature, 5(1), 1-8. DOI 10.37110/jell.v5i01.90
\end{abstract}

Received: 09-01-2020

Accepted: $30-01-2020$

Published:01-03-2020

\begin{abstract}
Code mixing can occur anywhere. Mixed code is a mixture of two or more languages. Code mixing occurs when a speaker using a language dominantly supports a speech inserted with other language elements. This paper is conducted to get data about code mixing, especially in delivered by the presenter in the Hijab Traveling in Trans7 television program. The research used descriptive qualitative research. The data were collected from utterances delivered by the presenter in the Hijab Traveling in Trans 7 television program. Process of analyzing the types of mixed code the writer used Suwito's theory. The results are 15 data found which the writer has classified into linguistic elements include the insertion of words, phrases, clauses, repetition of words, and idiom. Proses of analyzing the causes of mixed code the writer used the theory of Basir. The results are found 9 data. The result indicated that presenters on the Hijab Traveling in Trans7 television program often intervene in code. Based on all the analysis of data the writer can conclude that the sentences uttered by the presenter of Hijab Traveling in Trans7 television program prove that presenter often use mixed codes because the presenter can speak more than one language and the presenter has extensive knowledge.
\end{abstract}

Keywords: Code Mixing; TV Show; Hijab Traveling in Trans7 television program

\section{INTRODUCTION}

Linguistics comes from Latin "lingua" which means language. Linguistics is the science of language or science that makes language the object of study. In French there are three terms to refer to language, namely Langue is a particular language. Language is a language in general. Parole is a language in a tangible form that is a speech. Linguistic science is often also called general linguistics (general linguistics) that is linguistics not only studies a language, but also examines the ins and outs of language in general. Language which is a tool for human social interaction.

Language is the main way to communicate, without language it is difficult for people to understand what they want to say. Nowadays mastering foreign languages is very important especially for millennial children to be able to compete in the global world. Especially in the world of work, someone who has foreign language skills will be taken into account in his acceptance because they are considered to have more value. With more and more Indonesians learning foreign languages, in the communication process most Indonesians often mix the use of one language with another language or what can be called bilingualism, which is mastery of more than one language.

One of them is on a television program. The Hijab Traveling show on Trans7 is a soft but interesting news program called a feature. Hijab Traveling is a travel program that provides references to tourist attractions in a country with reference places to get halal food, mosques, and muslim communities around tourist attractions.

It is found when the speakers mix two languages or more to achieve their purposes, such as to state their thoughts, instructions, messages, or experiences so the listeners can receive what the speakers said perfectly. To be able to pull this off, speakers must acquire a sophisticated amount of knowledge of both languages cross-cultural communication norms first. Code mixing can be found not only in real life spoken or even overheard conversation.

Based on the description above, the writer likes to watch shows that show adventure to a place because the writer has a reference place to travel. Besides that, the writer are interested in examining the Hijab Traveling show where there are forms of mixed codes, types of mixed codes and factors that underlie the use 
of mixed codes used by presenters in the Hijab Traveling show on Trans7. Therefore, In this research, the analysis focuses on "Code Mixing In TV Show Entitled "Hijab Traveling" On Trans7".

Based on the background and reason of choosing the title above, the writer can identify those problems as follows: (1) What types of code mixes are contained in the Hijab Traveling program?; (2) What are the meanings of mixed code found in Hijab Traveling program?; and (3) What are the factors behind the mixed code in Hijab Traveling program?

\section{Literature Review}

These reviews are expected to serve important background information to support the study and the discussion of the findings. It is divided into three subtopics: (a) Definition of Sociolinguistics, (b) Meanings, (c) Song Lyric, (d) Message.

\section{Description of Sociolinguistics}

(Hudson, 1996) says, Sociolinguistics is the study of language in relation to society. In other words, in sociolinguistics we study language and society in order to find out as much as we can about what kind of thing language is, and in the sociology of language we reverse the direction of our interest." Basically, sociolinguistics studies how language and society affect each other in daily life.

Another definition is based on (Wardaugh, 1986) "Sociolinguistics is the study of stylistic and social variation of language." To make it short, sociolinguistics studies the structures of society and how a certain social background can affect the language used in a conversation between speaker and the addressee.Sociolinguistics studies language in its social context. This means, sociolinguistics involves diversity, variation, and also manifestation of said language within certain society.

Summing up all the definitions above, it can be understood that sociolinguistics is a study of how language and society relate to and affect each other in many ways. Language is a living thing that continues to grow as society develops itself from time to time. Language is built and shaped the way it is because of the structures and habits of said society.

\section{Description of Bilingualism}

(Myers-Scotton, 2005) states that, "Bilingualism is the term for speaking one or more languages. Usually the speakers' mother tongue or first language is one of the two languages that make them bilinguals. Bilingualism is used as a cover term for multilingualism, too - speaking more than two languages." So, bilingualism can be a label that is given to someone who speaks two languages, whereas one of the two is their native language.

To make it short, bilingualism is a term for people who master or properly functions a second language, even though they don't really always use it.
So, logically speaking and theory-supported by the experts above, it can be concluded that bilingualism refers to the ability of people of mastering (understanding, speaking, and writing) more than just one language - and in some cases, more than two.

\section{Description of Multilingualism}

(Bathia, 2013) says that, "The terms bilingualism and multilingualism have come to be used, respectively, to refer to the knowledge and use of two languages and the knowledge and use of three or more languages." This means, multilingualism is a term that is used to define a person that speaks more than two languages - three, four, and so on.

On the other hand, a lot of people still see the term multilingualism as a mere extension of bilingualism. Weinreich in (Aronin, Larissa \& Singleton, 2012) says that "...the practice of alternatively using two languages will be called here BILINGUALISM, and the persons involved BILINGUAL. Unless otherwise specified, all remarks about bilingualism apply as well to multilingualism, the practice of using alternatively three or more languages." So, whereas bilingualism society speaks two languages, multilingualism society speaks three or more languages.

So, logically speaking and theory-supported by the experts above, it can be concluded that multilingualism refers to the ability of people who can function well in more than two languages and use all the languages they master in their every day life.

\section{Description of Code Mixing}

Code mixing is using more than one languange in one sentence. It can be used in speaking and written expression, also. (Wardaugh, 1986) mentioned that "code mixing occurs when conversant uses both of language together to extend that they change from one language to the other in the course of a single utterance". So, it means that conversant uses more language in a single utterance, it can be said as code mixing. If it is not in a single utterance, it is not.

In another theory, (Nababan, 1991) says that "it is a mixing of two or more language or language variation in speech act or discourse without something in using language situation which demands the speaker, it is only because of informal and speaker habitual"

\section{Types of Code Mixing}

According to Suwito (Asokawati \& Winingsih, 2017) stated that Type of code mixing into (inner code mixing) If the source language with the target language still has kinship relationships geographically and geologically. (2). Type mixed code to the outside (outer code mixing). If the source language with the target language does not have kinship, geographically, geologically or politically. This mix of exit codes occurs due to high intellectual abilities, emitting moderate values)

Example

Inner Code Mixing 
Journal of English Language and literature

Volume 5, Issue 1,March 2020

Bapak Ibu para jamaah pengajian, ingkang kula hormati (Ladies and gentlemen of the recitation worshipers, which I respect)

\section{Outer Code Mixing}

Saya sedang tidak bisa berpikir,otakku blank. (I can't think my brain is blank)It means that mixed code into is a mix of code that comes from the original language with all its variations while mixed code out is a mixture of codes that come from foreign languages.

However, Suwito (Astuti, 2017) stated that distinguish types of mixing code based on the elements of languages, among others:

1) Insertion of elements that form word Word is the smallest unit of language consists of a morpheme or more than a morpheme.

Example: Tapi teks ini catchy banget, bos. (But this text is really catchy, boss)

2) Inserting elements that form phrase Phrase is grammatical analysis to refer to a single element of structure typically containing more than one words, and lacking the subject and predicate structure typical of clauses.

Example: Nah, yang satu lagi bentuknya buku seni, bentuknya coffee tablebook. (Well, the other is the format of art books, the shape of the coffe table book).

3) Insertion of elements in the form of baster. Baster is a combination of two elements and creates one meaning, the form of baster basically forms of English and there is an addition of Indonesian slang affixation or vice versa.

Example: Emang kadang mending nge-date pake sepeda kumbang daripada Fiat kuning $i t u$. (It is sometimes better to set up a beetle rather than the yellow fiat)

4) Insertion of elements that are repetitive word

Repetition word is a word formed because of words reduplication.

Example: Morning, morning guys.

5) Insertion of elements in the form of clause Clauses is a unit of grammatical organization smaller than the sentence, but larger than the phrases, words or morphemes and clause having a subject and predicate.

Example: Kamu tau kan kalo aku tuh sibuk, I just want to concern on my target. You know that I'm busy, I just want to concern on my target)

6) Insertion of elements in the form of expressions or idiom
p-ISSN 2540-8216, e-ISSN 2654-3745

https://journal.stibaiec-jakarta/ojs/index.php/jell

Idiom is group of words with a meaning that is different from the meaning of the individual word.

Example: Ide kamu itu baru banget, out of the box. (Your idea is really fresh, out of the box)

It describes that type mixed code based on linguistic elements include the word, phrase, baster, repetitive word, clause, idiom.

Another theory about types of code mixing is according to Muysken (Mujiono \& et al 2017) explained that mixed code has several types of formation, namely:

1) Insertion

Insertion occurs when lexical items from one language are incorporate into another.

Example: Tergantung leader, terus juga tergantung situation.

(It depends on the leader and on the situation)

2) Alternation

Alternation occurs when structures of two languages are alternated indistinctively both of the grammatical and lexical level.

Example: You mean, ganti ke kata lain.

(You mean, change it to another word)

3) Congruent lexicalization

Congruent lexicalization is a material from different lexicasl inventories into a shared grammatical structure.

Example: Software gua buat convert file wav jadi mp3 gua uda expired. (My software for converting wav files to mp3 has expired)

It means that insertion explains about mixing at a more restricted lexical level. Alternation is mixing at a structure level. Last Ones, congruent lexicalization is refers to two languages share grammatical structures which can be filled lexically with elements from either language.

\section{Factors of Code Mixing}

According to Suwito (Mustikawati, 2015) stated that "Membagi tiga penyebab atau alasan terjadinya campur kode yaitu; (1) identifikasi peranan, (2) identifikasi ragam, (3) keinginan untuk menjelaskan dan menafsirkan". (Divide three causes or reasons for code interference, namely; (1) identification of roles, (2) identification of variety, (3) desire to explain and interpret).

It implies that the code mix that occurs is intended to identify the role of the speaker, socially and educatively and identify the desire to explain and interpret appear in attitudes towards speakers. Speakers who mix code with certain language elements can give their own impression, meaning speakers who have a certain background tend to choose mixed codes to 
realize their social status and personal identification in society.

Ju (Setiadi, 2017 stated that: Beberapa faktor yang menyebabkan penggunaan campur kode adalah persepsi tentang latar belakang, dominasi bahasa, sikap bahasa, motivasi psikolinguistik, dan pencampuran dalam kata atau frasa".(Some of the factors that cause the use of mixed code are perceptions of background, language dominance, language attitude, psycholinguistic motivation, and mixing in words or phrases)

It means that speakers who want to display certain backgrounds tend to choose mixed codes to realize their social status and personal identification in the community, and from that mix code into everyday language style within the speaker.

Basir (Yulianti, 2016) defined that: Beberapa faktor yang menyebabkan terjadinya campur kode, yaitu (1) adanya keterbatasan padanan kata, (2) pengaruh pihak kedua, (3) kurangnya penguasaan kode yang di pakai, dan (4) pengaruh unsure prestise". (Some of the factors that cause code interference are (1) the limitation of word equivalents, (2) the influence of the second party, (3) the lack of mastery of the code used, and (4) the influence of prestige elements).

It asserts that speakers in using code mixing sometimes do not get matching matching words that can explain the actual purpose, the speaker will look for matching words that match the terms of the various languages that the speaker knows and the prestige element that speakers who have the ability to mix certain language codes want to look different compared to other people around them.

Some of the causes of the mixed code that have been explained above the writer conclude that identification of roles is more dominant as a factor whysomeone uses mixed code in communication because speakers want to be recognized for their social status and also look different than other communities.

\section{RESEARCH METHOD}

This writer used a descriptive qualitative analyzed method. Qualitative description analyzed is used to describe and analyze mixed codes used in TV shows. According to Aminudin (Nuwa,2017) stated that:
Metode kualitatif adalah penelitian yang menghasilkan data deskriptif berupa kata-kata tertulis atau lisan dengan orang-orang atau pikiran yang diamati".(Qualitative method is research that produces descriptive data in the form of written or oral words with people or thoughts observed). It means that qualitative descriptive method is a form of research that produces data in the form of words and not in the form of numbers.

Data were analyzed based on the speech delivered by the presenter in the Hijab Traveling show. In addition, in this paper the writer also uses data sources taken from TV shows on Trans7 to support this method. The source of data that is downloaded is data that will be selected and analyzed from each word spoken by the presenter. Then the conclusions from the data will be made to support the research idea.

\section{FINDING AND DISCUSSION}

In this section the writer finds the results of research in which there are types of code mixing, the meanings of the mixed code, and factors of mixed codes in the data source. Previously the writer explained in chapter 1 , the source of data obtained from each sentence spoken by the presenter in the Hijab Travel program. Data was obtained from 2 episodes in the Hijab Traveling program which had been aired on television on October 13th 2018 and on April 14th 2019.

\section{The Types of Code Mixing}

The writer in finding type of mixed codes used theory according to Suwito (Astuti, 2017). In analyzing the types of code mix the writer classifies mixed code according to linguistic elements such as word, phrase, clause, idiom, baster and repetitive words.

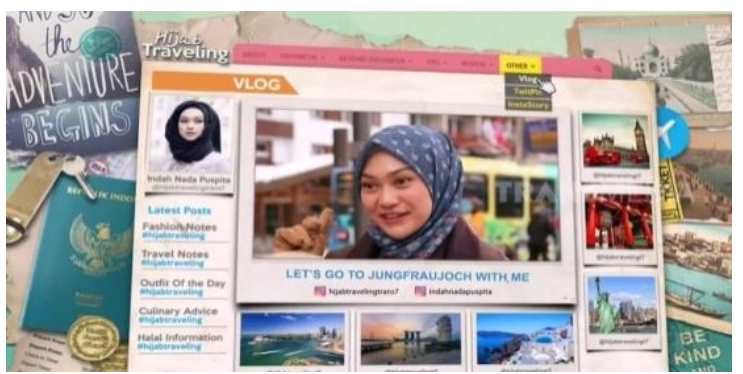

Figure I Video of "Jungfraujoch Top of Europe

\begin{tabular}{|c|c|c|c|c|c|c|c|}
\hline \multirow[t]{2}{*}{ No } & \multirow[t]{2}{*}{ Sentences } & \multicolumn{6}{|c|}{ Types of Code Mixing } \\
\hline & & Word & Phrase & Clause & Idiom & Baster & $\begin{array}{c}\text { Repetitive } \\
\text { Word }\end{array}$ \\
\hline 1 & $\begin{array}{l}\text { Sudah biasanya kan kalau orang- } \\
\text { orang datang ke Swiss highlight- } \\
\text { nya adalah kepuncak eropa }\end{array}$ & & $\checkmark$ & & & & \\
\hline 2 & $\begin{array}{l}\text { Nah kali ini Nada akan ajak sahabat } \\
\text { traveler ke top of view loh }\end{array}$ & & $\checkmark$ & & & & \\
\hline
\end{tabular}




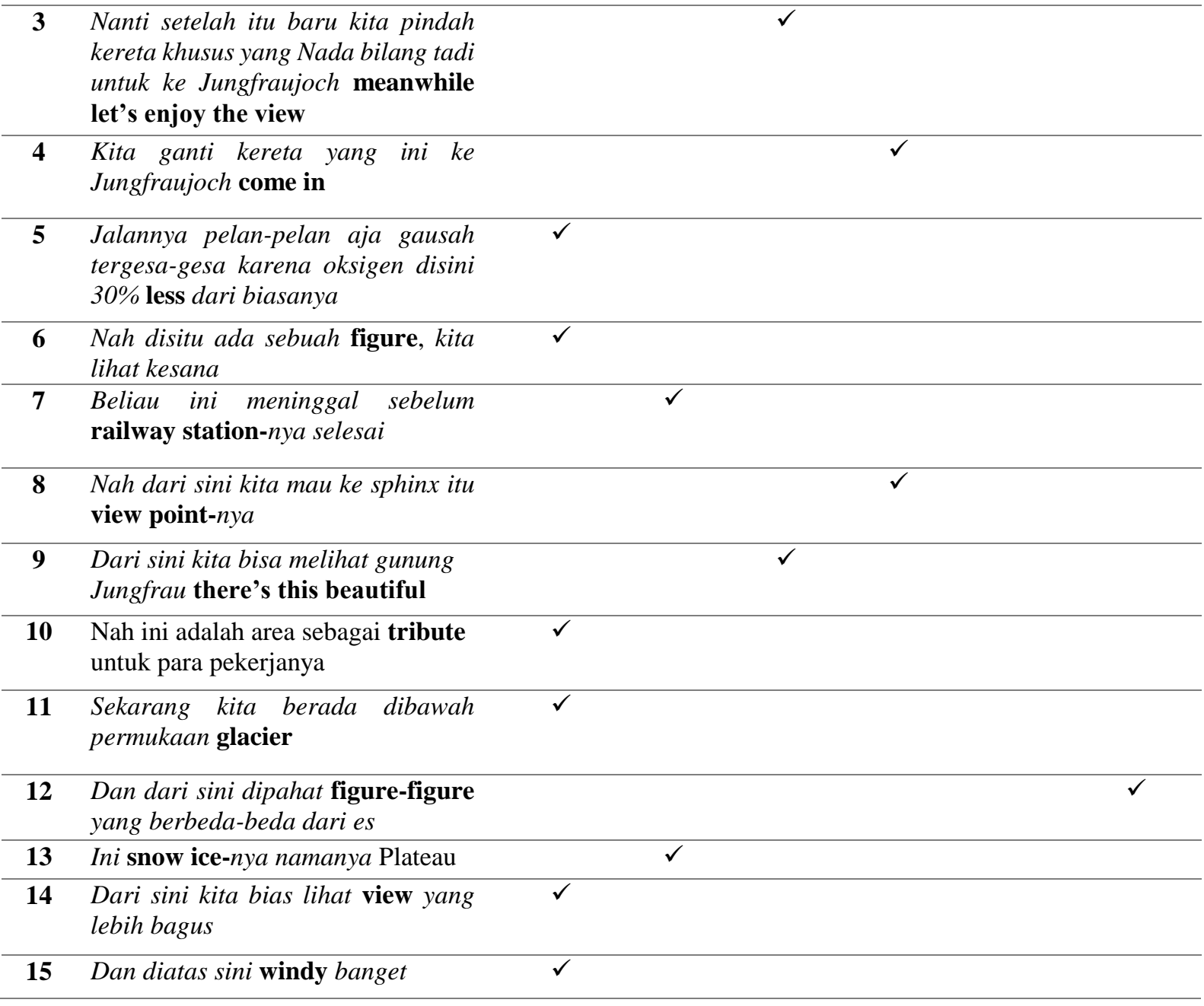

Based on data table 1 video of "Jungfraujoch Top of Europe" has been found there are 20 data included into types of code mixing. It can be classified into code mixing word are 8 data, code mixing phrase are 4 data, code mixing clause are 5 data, code mixing idiom are 2 data, code mixing repetitive word is 1 data.

\section{Meanings of Code Mixing}

In analyzing the meanings of code mix the writer finding the real meaning and then giving an explanation in the writer's own language.

Table.2 Video of "Jungfraujoch Top of Europe"

\begin{tabular}{clcl}
\hline No & \multicolumn{1}{c}{ Sentences } & $\begin{array}{c}\text { Types of } \\
\text { Code Mixing }\end{array}$ & \multicolumn{1}{c}{ Meanings of Code Mixing } \\
\hline $\mathbf{1}$ & $\begin{array}{l}\text { Sudah biasanyakan kalau orang- } \\
\text { orang datang ke Swiss highlight- } \\
\text { nya adalah ke puncak eropa }\end{array}$ & Phrase & $\begin{array}{l}\text { The code mixing phrase written by the writer is } \\
\text { highlight. The phrase is included into noun } \\
\text { phrase. In this sentence the presenter state that } \\
\text { people who visit Switzerland are usually the main } \\
\text { destination to the top of Europe. }\end{array}$ \\
\hline $\mathbf{2}$ & $\begin{array}{l}\text { Nah kali ini Nada akan ajak } \\
\text { sahabat traveler ke top of view } \\
\text { loh }\end{array}$ & Phrase & $\begin{array}{l}\text { The code mixing phrase written by the writer is to } \\
\text { view. The phrase is included into noun phrase. In } \\
\text { sentence, the presenter express her emotion to start } \\
\text { journey. }\end{array}$ \\
\hline $\begin{array}{l}\text { Nanti setelah itu baru kita pindah } \\
\text { kereta khusus yang Nada bilang } \\
\text { tadi untuk ke Jungfraujoch } \\
\text { meanwhile let's enjoy the view }\end{array}$ & Clause & $\begin{array}{l}\text { Meanwhile is conjunctive adverb which shows } \\
\text { time. And let's enjoy the view is simple sentence. } \\
\text { In this sentence, the presenter want to show the } \\
\text { view at the Jungfraujoch }\end{array}$ \\
\hline
\end{tabular}




\begin{tabular}{|c|c|c|c|}
\hline 4 & $\begin{array}{l}\text { Kita ganti kereta yang ini ke } \\
\text { Jungfraujoch come in }\end{array}$ & Idiom & $\begin{array}{l}\text { The code mixing idiom is come in. Come on } \\
\text { means To enter a place, to arrive at a } \\
\text { particularplace or destination. In that sentence the } \\
\text { presenter want to show the next train to } \\
\text { Jungfraujoch. }\end{array}$ \\
\hline 5 & $\begin{array}{c}\text { Jalannya pelan-pelan aja gausah } \\
\text { tergesa-gesa karena oksigen } \\
\text { disini 30\%less dari biasanya }\end{array}$ & Word & $\begin{array}{l}\text { The code mixing word is the word less. The word } \\
\text { less here has a meaning kurang atau sedikit in } \\
\text { Indonesia Language. In this sentences, show that } \\
\text { in a state of lack of oxygen because it is at } 3454 \mathrm{~m} \\
\text { above sea level }\end{array}$ \\
\hline 6 & $\begin{array}{l}\text { Nah disitu ada sebuah figure, kita } \\
\text { lihat kesana }\end{array}$ & Word & $\begin{array}{l}\text { The code mixing word is the word figure. It's } \\
\text { included into noun which has a meaning bentuk } \\
\text { badan in Indonesia language. In here, explain that } \\
\text { there is a figure of a builder Jungfraujoch railway } \\
\text { station }\end{array}$ \\
\hline 7 & $\begin{array}{l}\text { Beliau ini meninggal sebelum } \\
\text { railway station-nya selesai }\end{array}$ & Phrase & $\begin{array}{l}\text { Phrasein the sentence is railway station. It's } \\
\text { included into noun phrase. Railway station is a } \\
\text { departure or train stop terminal where passengers } \\
\text { can go up and down using the train transportation } \\
\text { mode. }\end{array}$ \\
\hline 8 & $\begin{array}{l}\text { Nah dari sini kita mau ke sphinx } \\
\text { itu view point-nya }\end{array}$ & Idiom & $\begin{array}{l}\text { The code mixing idiom is view point. View point } \\
\text { means the way of thinking about something. In } \\
\text { that sentence, the presenter want to show sphinx. } \\
\text { The sphinx is the place of an observatory to } \\
\text { research astronomy. }\end{array}$ \\
\hline 9 & $\begin{array}{l}\text { Dari sini kita bisa melihat gunung } \\
\text { Jungfrau there's this beautiful }\end{array}$ & Clause & $\begin{array}{l}\text { There's this beautiful is a simple sentence. This } \\
\text { sentence describe that Jungfrau mountain has a } \\
\text { beautiful view. }\end{array}$ \\
\hline 10 & $\begin{array}{l}\text { Nah ini adalah area sebagai } \\
\text { tribute untuk para pekerjanya }\end{array}$ & Word & $\begin{array}{l}\text { The code mixing word is the word tribute. It's } \\
\text { included noun. Tribute means penghormatan in } \\
\text { Indonesia language. In here, has a meaning a place } \\
\text { of respect for workers who have built a train } \\
\text { station. }\end{array}$ \\
\hline 11 & $\begin{array}{l}\text { Sekarang kita berada dibawah } \\
\text { permukaan glacier }\end{array}$ & Word & $\begin{array}{l}\text { The code mixing word is the word glacier. It's } \\
\text { include noun. Glacier means sungai es in } \\
\text { Indonesian language. In here, explain that the } \\
\text { presenter is at } 20 \mathrm{~m} \text { below the glacier surface. }\end{array}$ \\
\hline 12 & $\begin{array}{l}\text { Dan dari sini dipahat figure- } \\
\text { figure yang berbeda-beda dari es }\end{array}$ & $\begin{array}{l}\text { Repetitive } \\
\text { Word }\end{array}$ & $\begin{array}{l}\text { The code mixing reduplication is figure-figure } \\
\text { because there are } 2 \text { words figure. The sentences } \\
\text { show that there are many figures statues made of } \\
\text { ice. }\end{array}$ \\
\hline 13 & Ini snow ice-nya namanya Plateau & Phrase & $\begin{array}{l}\text { Phrase in the sentence is snow ice. It's included } \\
\text { into noun phrase. The sentence explain that } \\
\text { Plateau is a place called the top of Europe to see } \\
\text { ice snow. }\end{array}$ \\
\hline 14 & $\begin{array}{l}\text { Dari sini kita bias lihat view yang } \\
\text { lebih bagus }\end{array}$ & Word & $\begin{array}{l}\text { The code mixing word is the word view. It's } \\
\text { include noun. View means pemandangan in } \\
\text { Indonesia language. In the sentence, explain that } \\
\text { beautiful view on the Jungfraujoch. }\end{array}$ \\
\hline 15 & Dan diatas sini windy banget & Word & $\begin{array}{l}\text { The code mixing word is the word windy. It's } \\
\text { include adjective. Windy means berangin or in } \\
\text { this sentence it means really cold. }\end{array}$ \\
\hline
\end{tabular}

Based on all data from table .2 video of "Jungfraujoch Top of Europe" and " that has been found there are 20 data the writer has classified according to Suwito's theory. Then the writer defines the meaning of the mixed code contained in the data. The process of searching for mixed code meaning, the writer translates 
from English to Indonesian. In addition, the writer also explains how to use one's own language so that it is better understood by the reader.

\section{Factors of Using Code Mixing}

The writer uses the theory from Basir to analyze the factors that cause the use of mixed codes used by presenters from Hijab Traveling program traveling on Trans7.

Data 1

Presenter: Tapi sebelumnya dari tempat nada stay di Grindelwald Nada harus naik kereta dulu dari KleineScheidegg (But beforehand from where the tone of stay in Grindelwald Nada had to take the train first from Kleine Scheidegg). In the sentence above, the writer found the factor that caused the presenter to use mixed code is the lack of mastery of the code use.. The presenter in her speech inserted the word "stay". Presenter uses a mix of English language codes, the word "stay" intended to be better understood by the audience of Hijab Traveling program and the word "stay" is very familiar for tourist programs.

Data 2

Presenter: Beliau adalah pencetus dari pembangunan Jungfraujoch railway station ini namanya Adolf Guyer Zelter (He was the originator of the construction of the Jungfraujoch railway station called Adolf GuyerZelter), In the sentence above, the writer found the factor that caused the presenter to use mixed code is the influence of prestige elements. The presenter in her speech told the history of the figure who built the Jungfraujoch railway station.

Data 3

Presenter: Nah tadi Nada dapat ini, iniseperti passport, Jungfrau railway passport, nah ini ada alat untuk stem, begitu Nada stem kaya giniya Nada udah official pernah ke Jungfrau" (Well, you got this Nada, this is like a passport, Jungfrau railway passport, now there is a tool for stemming, that's Nada the stem like this, Nada already official has been to the Jungfrau).

In the sentence above, the writer found the factor that caused the presenter to use mixed code is the limitation of word equivalents. The presenter in her speech inserted the words "passport" and "stem". This happen because presenter find it difficult to find the equivalent of passport and stem in Indonesia language.

Data 4

Presenter: Oksigennya cumin sedikit I mean $30 \%$ less dari biasanya, (The oxygen is only a little. I mean $30 \%$ less than usual). In the sentence above, the writer found the factor that caused the presenter to use mixed code is the limitation of word equivalents. The presenter in her speech inserted the words "I mean" and "less". This happen because presenter find it difficult to find the equivalent of I mean and less in Indonesia language. And this can also happen because the presenter is in a bad condition so the presenter says only what is in her mind.

\section{Data 5}

Presenter: Jadi kalau summer nah di area sini jadi snow fun, kita bisa sledging dari sini (So if it's summer in this area, it's snow fun, we can sledging from here).

In the sentence above, the writer found the factor that caused the presenter to use mixed code is the limitation of word equivalents. The presenter in her speech inserted the word "sledging". This happen because presenter find it difficult to find equivalent of sledging in Indonesia language. Sledging means keretaluncur in Indonesian language. In the sentence above sledging has a meaning winter sports which are usually done in a prone position or sitting on a vehicle.

Data 6

Presenter: Keren banget kalau sledging disini pas summer karena basically kalian sledging diatas awan (It's really cool that sledging here is summer because basically you guys sled over the clouds ). In the sentence above, the writer found the factor that caused the presenter to use mixed code is the limitation of word equivalents. The presenter in her speech inserted the word "sledging" repeatedly. This happen because presenter find it difficult to find equivalent of sledging in Indonesia language.

\section{Data 7}

Presenter: Disana ada dataran salju yang luas nah itu sebenarnya adalah aletsch glacier jadi glacier itu panjang banget

(There is a vast plain of snow that is actually a glacier aletsch so it's a really long glacier). In the sentence above, the writer found the factor that caused the presenter to use mixed code is the influence of prestige elements. The presenter is knowledgeable about the interesting things at the Jungfraujoch, there are aletsch glacier. Aletsch Glacier is the largest glacier in the Alps, Switzerland.

\section{Data 8}

Presenter: Kalau mau experience nonton flying chicken kaya Nada tadi bias dating kerestoran kalau mau di servenya halal telfon dulu sehari sebelum dating (If you want to experience watching a chicken that is like Nada, you can come to a restaurant if you want to offer halal telephone first a day before you arrive). In the sentence above, the writer found the factor that caused the presenter to use mixed code is the lack of mastery of the code used. The presenter in her speech inserted the word "flying chicken". The presenter find it difficult to find equivalent of flying chicken in Indonesia language because the term flying chicken meant by the presenter is an attraction or a way of serving food in one of the restaurants in Bangkok, Thailand.

\section{Data 9}

Presenter: Nada mau habisin dulu makanannya bersama Mark Wiens so let's finish our foods (Nada wants to finish the food with Mark Wiens first so let's finish our foods). In the sentence 


\section{Sri Arfani and Nafiah Mahmudah}

Code mixing in TV show entitled Hijab Traveling on Trans 7.

above, the writer found the factor that caused the presenter to use mixed code is the influence of the second party. The presenter in her speech using mixed English code because the presenter reviewed the food accompanied by a food vlogger from America namely Mark Wiens.

Based on data that has been found there are 9 data included into factors of using code mixing. The data are classified according to Basir's theory. It can be classified into the limitation of word equivalents are 4 data, the influence of the second party is 1 data, the lack of mastery of the code used are 2 data, the influence of prestige elements are 2 data.

\section{CONCLUSION}

Process of analyzing the types of mixed code the writer used Suwito's theory. The results are 20 data found which the writer has classified into linguistic elements include the insertion of words, phrases, clauses, repetition of words, idiom. All data included in the types of code mix has been interpreted by the writer

\section{REFERENCES}

Aronin, L and Singleton, D. (2012). Multilingualism. Philadelphia: John Benjamins Publishing Co.

Bathia, Tej and William C. Ritchie (eds). (2013). Second edition. The Handbook of Bilingualism and Multilingualism. Malden, MA \& Oxford, UK: Wiley-Blackwell

Hoffman, C. (1991). An Introduction to Bilingualism. London: Longman

Hudson, R. A. (1996). Sociolinguistics. Cambridge: Cambridge University Press.

Myers-Scotton, C. (2005). Multiple Voices: An Introduction to Bilingualism. Toronto: Blackwell Publishing.

\section{Biography}

Her name is Dr. Sri arfani, M.Pd. She was born on 25 Nofember 1973 in Bima west of Nusa Tenggara. She is an English lecturer of Communication and Language Faculty Bina Sarana Informatika University Jakarta. She started her career as English lecturer of UBSI in and explained in the writer's own language. After the writer analyzed the type of mixed code by classifying according to linguistic elements, then the writer analyzed the meaning of the mixed code contained in the data. The results are 15 data the writer has explained the meaning of mixed code that is spoken by the presenter on the Hijab Traveling television program. The last is data about the factors that caused the code mixed. Proses of analyzing the causes of mixed code the writer used the theory of Basir. The results are found 9 data. It can be classified into the limitation of word equivalents, the influence of the second party, the lack of mastery of the code used, the influence of prestige elements. Based on all the analysis of data the writer can conclude that the sentences uttered by the presenter of Hijab Traveling television program prove that presenter often use mixed codes because the presenter can speak more than one language and the presenter has extensive knowledge.

Nababan, P.W.J. (1991). Sosiolinguistik Suatu Pengantar. Jakarta : PT Gramedia Pustaka Utama

Pieter, M, Bilingual speech: a typology of codemixing. Cambridge: Cambridge University Press, 2000

Suandi, I N. 2014. Sosiolinguistik. Yogyakarta: Graha Ilmu

Suwito. (1988). Sosiolinguistik. Surakarta: Universitas Sebelas Maret

Wardaugh, R. (1986). An Introduction to Sociolinguistic. Oxford: Basil Black Well.

2004 until now. She graduated from UNHAS Ujung Pandang in 1998, and continued her education to S2 degree in 2010 at UHAMKA Jakarta, then, continued her study in doctoral degree of UNJ in 2014 and graduated in 2017. She is available at sri.saf@bsi.ac.id 